\title{
An Mhc Component to Kin Recognition and Mate Choice in Birds: Predictions, Progress, and Prospects
}

\section{Citation}

Zelano, Bethanne and Scott V. Edwards. 2002. An Mhc component to kin recognition and mate choice in birds: Predictions, progress, and prospects. In Christine R. Boake and Allen J. Moore, ed., Behavior Genetics for the Next Decade: Beyond Heritability. Special Issue, American Naturalist 160(S6): S225-S237.

\section{Published Version}

http://dx.doi.org/10.1086/342897

\section{Permanent link}

http://nrs.harvard.edu/urn-3:HUL.InstRepos:2689350

\section{Terms of Use}

This article was downloaded from Harvard University's DASH repository, and is made available under the terms and conditions applicable to Other Posted Material, as set forth at http:// nrs.harvard.edu/urn-3:HUL.InstRepos:dash.current.terms-of-use\#LAA

\section{Share Your Story}

The Harvard community has made this article openly available.

Please share how this access benefits you. Submit a story.

Accessibility 


\title{
An Mhc Component to Kin Recognition and Mate Choice in Birds: Predictions, Progress, and Prospects
}

\author{
Bethanne Zelano and Scott V. Edwards
}

Department of Zoology, University of Washington, Seattle, Washington 98195

ABSTRACT: The major histocompatibility complex $(M h c)$ has been identified as a locus influencing disease resistance, mate choice, and kin recognition in mammals and fish. However, it is unclear whether the mechanisms by which $M h c$ genes influence behavior in mammals are applicable to other nonmammalian vertebrates such as birds. We review the biology of $M h c$ genes with particular reference to their relevance to avian mating and social systems. New genomics approaches recently have been applied to the Mhcs of chickens, quail, and several icons of avian behavioral ecology, including red-winged blackbirds (Agelaius phoeniceus) and house finches (Carpodacus mexicanus). The predominance of concerted evolution at avian Mhc loci makes such methods attractive for providing access to this complicated multigene family. Although some biological processes influenced by $M h c$ in mammals are physiologically implausible for birds, Mhc could influence cues that form well-known bases for mate choice in birds by influencing the health and vigor of individuals. The tight associations of $M h c$ variation and disease resistance in chickens raise hope that finding associations of $M h c$ genes, disease, and mate choice in natural populations of birds will be as fruitful as in mammalian systems.

Keywords: cooperation, QTL, kin selection, genome-enabled science, extrapair fertilizations.

The major histocompatibility complex $(M h c)$ is a highly polymorphic set of genes encoding receptors for antigen presentation to $\mathrm{T}$ lymphocytes of the immune system (Janeway et al. 1999). Mhc molecules bind short amino acid fragments derived from both self proteins and foreign antigens broken down within cells and display the fragments on the cell surface. $T$ cells recognize and bind the $M h c$-foreign antigen complex, thereby initiating a chain of events to stimulate the adaptive immune response to

\footnotetext{
* Corresponding author. Address for correspondence: Department of Zoology, University of Washington, Box 351800, Seattle, Washington 98195; e-mail: sedwards@u.washington.edu.
}

Am. Nat. 2002. Vol. 160, pp. S225-S237. (c) 2002 by The University of Chicago. 0003-0147/2002/16006S-0007\$15.00. All rights reserved.

fight infection. It is now well appreciated that $M h c$ polymorphism plays a central role in resistance to infectious and autoimmune disease in birds and mammals (Briles et al. 1983; Kaufman and Wallny 1996; Hill 1999). Soon after the proximate molecular functions of $M h c$ genes were elucidated, it was also recognized that, by nature of their role in self-nonself recognition and high polymorphism, $M h c$ genes could play a role in kin recognition and mate choice (Yamazaki et al. 1976). The role of $M h c$ in social interactions most thoroughly has been explored in mammals (reviewed in Brown and Eklund 1994; Jordan and Bruford 1998; Penn and Potts 1999; Tregenza and Wedell 2000). Although the evidence is compelling that the avian immune system is comparable to that of mammals in its disease fighting ability (Kaufman et al. 1999b), basic differences in the evolution and architecture between mammalian and avian $M h c$ genes make it is less clear whether avian mating and kin recognition systems might contribute to Mhc polymorphisms as in mammals (discussed below). We synthesize information on avian molecular genetics and behavioral ecology to illustrate how these two disciplines can be linked through examinations of $M h c$ influences on behavior.

\section{Mhc Genes and Gene Products}

Classical class I and class II Mhc molecules are usually highly polymorphic and play critical roles in antigen presentation for T cell-mediated and humoral immunity, respectively (Janeway et al. 1999). The high polymorphism is confined to a particular domain in class I and II molecules called the peptide-binding region (PBR), which directly contacts pathogen fragments at specific amino acid sites. The Mhc holds a special place among initiators and regulators of immune responses because of its action during early stages of the adaptive immune response, its role in shaping the $\mathrm{T}$ cell repertoire during individual ontogeny (Schaffer et al. 1989; Penn and Potts 1999), and its influence on the response to pathogens by antibodies (Puel and Mouton 1996). For example, the Mhc class II region can effectively act as a quantitative trait locus (QTL) in the 


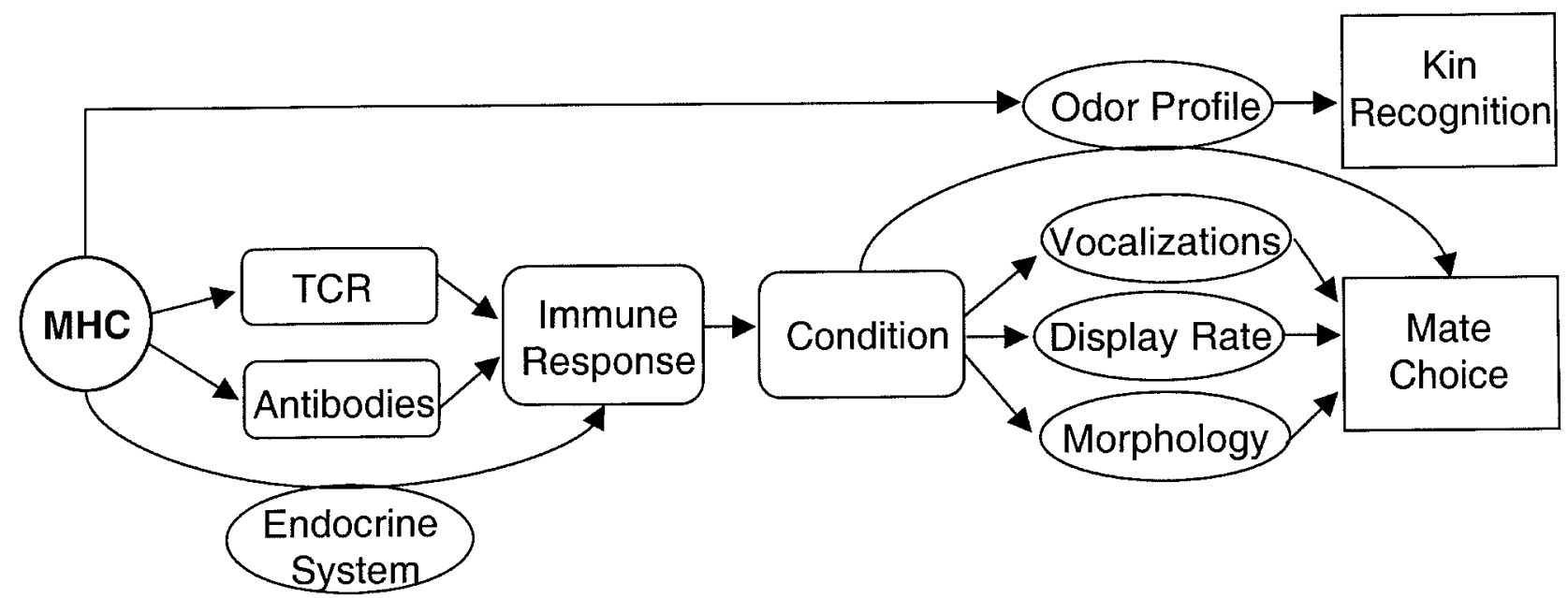

Figure 1: Flow chart outlining the major relationships between major histocompatibility complex variation, individual condition, mate choice, and kin recognition. The primacy of $M h c$ genes in modulating both the T-cell repertoire and the humoral (antibody) immune response is indicated at left. We envision $M h c$ as having an effect on mate choice primarily through condition-dependent traits but with an effect on kin recognition directly through olfactory or other mechanisms.

humoral (antibody) immune response (Puel and Mouton 1996), suggesting strong pleiotropic effects on diverse aspects of immune function. Thus, the $M h c$ is a crucial fulcrum that potentially unites both cell-mediated and humoral responses to pathogens in the wild. Because of the $M h c$ 's myriad effects on the adaptive immune response, it will be important to examine possible $M h c$ correlates of variation in antibody-based immunocompetence in the future.

Mhc genes likely influence diverse aspects of individual phenotype, with consequences for odor profile and individual condition affecting physiological resources available for display, territory acquisition, and defense (figs. 1, 2). While specific Mhc haplotypes may provide indirect (future generation) benefits of mate choice as "good genes," they also may affect the ability of an individual to amass resources such as territory and food that typically constitute direct (within-generation) benefits of mate choice (fig. 2 ). In addition, it is likely that the adaptive immune response and the action of $M h c$ genes are influenced directly or indirectly by circulating hormones such as testosterone or corticosterone (Hillgarth and Wingfield 1997). For example, testosterone induces the proliferation of certain T cell populations in male chickens (Arstila and Lassila 1993), and, conversely, Mhc type can influence serum testosterone levels in mammals (Gerencer et al. 1982; Larsen et al. 2000). Thus $M h c$ genes are best viewed as important defenses against parasites that modulate and are modulated by diverse biological systems.
Genetically encoded kin recognition systems must by their very nature be highly polymorphic in outbred populations (Grafen 1990); these may have evolved from polymorphic loci present in invertebrates. Although there is as yet little data suggesting direct homology between the histocompatibility locus in the marine tunicate Botryllus and the vertebrate Mhc (Magor et al. 1999), it is possible that polymorphism per se could have first been used in a nondisease context for genetic compatibility and then coopted to improve non-self-recognition in the context of disease (Penn and Potts 1999). Jordan and Bruford (1998) point out that the existence of $M h c$ loci on multiple chromosomes in several fish species would permit independent segregation of a larger number of "matching loci" than if all the $M h c$ genes were physically close to one another and presumably in strong linkage disequilibrium, as in mammals. However, when multiple $M h c$ genes are linked on the same chromosome, the more relevant parameter may be the extent of recombination between the loci. Recent data from red-winged blackbirds (Agelaius phoeniceus) suggest that, on an evolutionary timescale, recombination in the neighborhood of $M h c$ class II genes may be quite high, higher than has been observed among chicken $M h c$ genes through pedigree analysis (Garrigan and Edwards 1999; M. Smith and S. V. Edwards, unpublished data). Thus, the molecular genetic forces acting on $M h c$ genes clearly have relevance for the opportunity for behaviormediated selection (Jordan and Bruford 1998). 


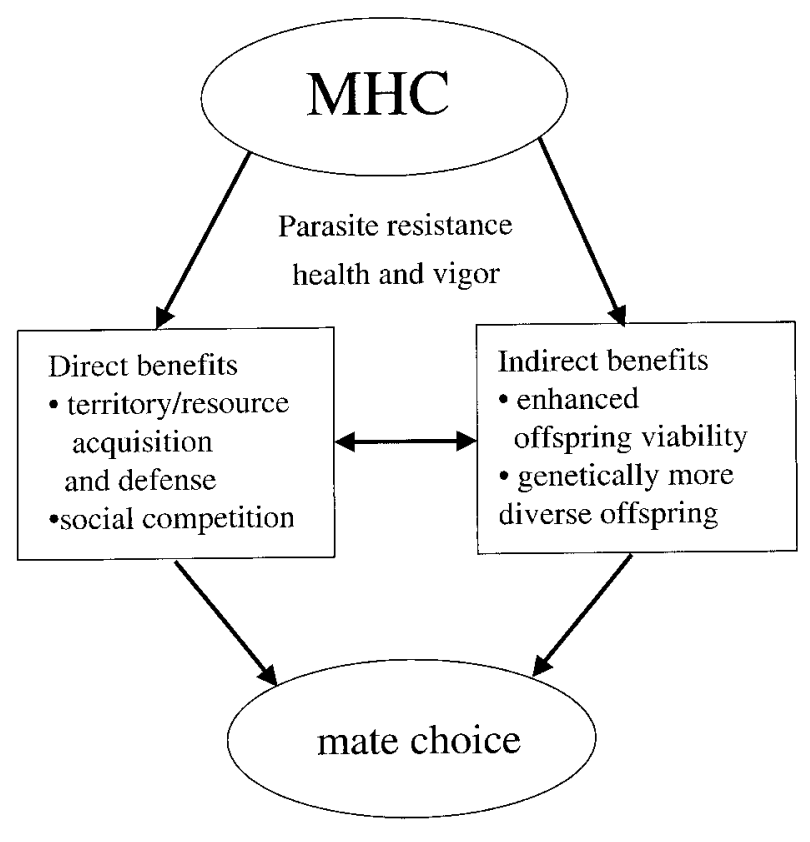

Figure 2: Schematic highlighting the redundancy of indirect and direct benefits to mate choice driven by $M h c$ genes, or other "good genes." The high pleiotropy of $M h c$ genes means that basic ecological activities, such as early arrival on and defense of territories, are likely a product of genetic variation as well as traditionally assumed "good genes" indicators, such as plumage and display rate.

\section{Selection for Diversity at Major Histocompatibility Complex Genes}

Genes of the Mhc are the most polymorphic genes known. Both pathogen- and non-pathogen-driven forms of selection have been proposed for the maintenance of the extraordinarily high levels of Mhc polymorphism and diversity found in natural populations, although it is likely that both selective forces have played complementary roles in the evolution of these genes (for review, see Potts and Slev 1995; Apanius et al. 1997).

\section{Pathogen-Driven Selection}

Pathogen-driven selection theories include heterozygote advantage (overdominant selection), frequency-dependent selection (Slade and McCallum 1992; Potts and Slev 1995), and the Red Queen hypothesis (Van Valen 1973; reviewed in Penn and Potts 1999). A general assumption of heterozygote advantage models is that individuals heterozygous at Mhc loci may be able to elicit more efficient defenses against a greater diversity of pathogens than more homozygous individuals. Evidence for heterozygote advantage is limited to a few examples of pathogen resistance in humans involving hepatitis B (Thursz et al. 1997) and
HIV (Carrington et al. 1999) and to resistance by chickens to Rous sarcoma virus (Senseney et al. 2000). In some cases, the heterozygotes in a population may have, on average, higher fitness than do the homozygotes, even though no heterozygote has a higher fitness than the two corresponding homozygotes ("population heterozygote advantage"); in other cases, certain heterozygote genotypes will actually have higher fitness than either corresponding homozygote ("allele-specific overdominance"; M. Lipsitch, C. T. Bergstrom, and A. Rustom, unpublished manuscript). The distinction is important. A finding of population heterozygote advantage, in which the class of individuals that are heterozygous for any $M h c$ alleles are overrepresented, as, say, survivors in a disease study, does not necessarily indicate that overdominance is occurring; the precise interpretation of this result depends on allele frequencies, and, surprisingly, such a result can in fact indicate that every heterozygote does worse than their corresponding homozygote (M. Lipsitch, C. T. Bergstrom, and A. Rustom, unpublished manuscript). According to frequency-dependent models of selection, rare alleles are presumed to have a selective advantage and will increase in frequency. There are examples in birds (Briles et al. 1983) and fish (Langefors et al. 2001) of strong associations between $M h c$ alleles and parasite resistance, which may be the result of such cycles of host/parasite evolution (see below). However, identifying the precise mode of selection from static association studies can be challenging without experimental approaches or long-term studies.

\section{Non-Pathogen-Driven Selection Mechanisms in Mammals}

Prenatal selection and disassortative mating are among the non-pathogen-driven modes of selection proposed to maintain diversity at these loci, and both can result in a deficiency of homozygotes at Mhc haplotypes (Alberts and Ober 1993). While prenatal selection at the maternal-fetal interface is possible in viviparous mammals, the reproductive physiology of oviparous animals, such as birds, precludes many interactions of this type (for review, see Apanius et al. 1997). Mhc is well known to influence mate choice, individual recognition, selective block of pregnancy, and nesting patterns through olfactory cues in rodents (many articles from K. Yamazaki's group; reviewed in Penn and Potts 1999; Schaefer et al. 2001) and has a role in odor preferences and miscarriage in humans (Wedekind and Füri 1997; Ober et al. 1998; Jacob et al. 2002) and other primates (Knapp et al. 1996). In birds, as in rodents, $M h c$-influenced precopulatory mechanisms of selection could include disassortative mating and kin recognition for inbreeding avoidance. Prelaying (and postcopulatory) mechanisms could include sperm competition and egg-sperm interactions; however, it is not yet known 
Table 1: Summary of molecular information available for avian $M h c$ genes

\begin{tabular}{|c|c|c|c|}
\hline Species & Class I & Class II & Progress to date \\
\hline Chicken (Gallus gallus) & Yes & Yes & $\begin{array}{l}\text { B complex completely sequenced; some Rfpy genes } \\
\text { polymorphic (Kaufman et al. 1999b; Afanassieff et } \\
\text { al. 2000) }\end{array}$ \\
\hline Japanese quail (Coturnix japonica) & Yes & Yes & $\begin{array}{l}\text { Mhe completely sequenced (Shiina et al. 1999; T. } \\
\text { Shiina, personal communication) }\end{array}$ \\
\hline Ring-necked pheasant (Phasianus colchichus) & & Yes & $\begin{array}{l}\text { cDNA sequence data for coding regions (Wittzell et } \\
\text { al. 1999a) }\end{array}$ \\
\hline \multicolumn{4}{|l|}{$\begin{array}{l}\text { Northern bobwhite (Colinus virginianus) and } \\
\text { masked bobwhite (Colinus virginianus }\end{array}$} \\
\hline ridgwayi) & Yes & & $\begin{array}{l}\text { Immunogenetic analysis and multilocus DNA finger- } \\
\text { printing (Drake et al. 1999) }\end{array}$ \\
\hline $\begin{array}{l}\text { Florida sandhill cranes (Grus canadensis } \\
\text { pratensis) }\end{array}$ & Yes & & RFLP and SSCP analyses (Jarvi et al. 1999) \\
\hline Great reed warbler (Acrocephalus arundinaceus) & Yes & Yes & $\begin{array}{l}\text { Sequence data from class I and II coding regions; } \\
\text { RFLP studies (Westerdahl et al. 2000) }\end{array}$ \\
\hline House finch (Carpodacus mexicanus) & & Yes & $\begin{array}{l}\text { Large-scale genomic sequence data for one pseudo- } \\
\text { gene (Hess et al. 2000) and coding region data } \\
\text { (Edwards et al. 1995) }\end{array}$ \\
\hline European starling (Sturnus vulgaris) & Yes & & RFLP analyses (Wittzell et al. 1999b) \\
\hline Red-winged blackbird (Agelaius phoeniceus) & & Yes & $\begin{array}{l}\text { Large-scale genomic sequence data for three genes } \\
\text { (Gasper et al. 2001) and coding region sequence } \\
\text { data (Edwards et al. 1995) }\end{array}$ \\
\hline Western scrub jay (Aphelocoma californica) & & Yes & PCR analyses of coding regions (Edwards et al. 1995) \\
\hline Willow warbler (Phylloscopus trochilus) & Yes & Yes & RFLP analysis (Westerdahl et al. 2000) \\
\hline Darwin’s finches (Geospiza spp.) & & Yes & PCR survey of partial sequences (Vincek et al. 1997) \\
\hline Bengalese finch (Lonchura striata) & & Yes & cDNAs cloned and characterized (Vincek et al. 1995) \\
\hline
\end{tabular}

Source: Hess and Edwards 2002.

Note: "Yes" indicates which class of $M h c$ has been characterized for each species.

if $M h c$ is expressed on avian sperm. Although $M h c$ antigen expression on human sperm is a contentious area of research, one hypothesis suggests that HLA 1 and 2 expression on sperm may function to prevent fertilization of ova by sperm with similar or identical Mhc (Martin-Villa et al. 1999); this proposed mode of selection in humans potentially applies to birds as well. We can further speculate that genetic compatibility at the Mhc in birds could have effects, by selection against embryos before hatching, analogous to abortion in mammals (for review of mammalian selection mechanisms see Wedekind 1994). Evidence from congenic lines of chickens suggests that there may be differential hatchability among $M h c$ haplotypes (Abplanalp et al. 1992).

\section{Genomics of the Avian Mhc}

Recent years have seen the complete sequencing of the chicken and Japanese quail (Coturnix japonica) Mhc regions (Kaufman et al. 1999a; Shiina et al. 1999). These accomplishments have come about because of a shift away from polymerase chain reaction (PCR) methods to programs embracing modern genomics approaches, such as cosmid cloning, shotgun sequencing, and bioinformatics. (Cosmid cloning has long been used to characterize medium-sized [25-40 kb] segments of genomic DNA; shotgun sequencing is a method for determining the sequence of such clones through DNA fragmentation and subcloning. See Edwards et al. 2000a for details.) Such methods are readily applicable to species of birds and other vertebrates that are models for ecological and behavioral biology (table 1; Edwards et al. 2000a). Such global characterization of $M h c$ genes and flanking regions can considerably facilitate genotyping for behavioral studies. For example, $M h c$ genes often occur physically close to microsatellites and frequently display tight linkage disequilibrium with them. Typing such length-variable microsatellites is technically often easier than typing the $M h c$ genes themselves (Meager and Potts 1997; Paterson et al. 1998), particularly in light of the fact that $M h c$ genes are now known to undergo extensive concerted evolution (Edwards et al. 1995; Wittzell et al. 1999a). Concerted evolution is a molecular process whereby different genes within a species exchange sequence information, by gene conversion or other mechanisms. Although the ultimate causes of this process are poorly known-indeed, con- 
certed evolution seems to contradict the paradigm that diversity, both within and among $M h c$ genes, is paramount-the result is increased sequence similarity and close relationships among different genes along the chromosome; in the case of avian Mhc genes, such increased similarity is particularly prevalent in regions outside the PBR (Edwards et al. 1995; Wittzell et al. 1999a). The practical consequence of concerted evolution is that amplification of individual $M h c$ genes becomes difficult because of the increased sequence similarity between genes. Because of this, analysis of variation at individual Mhc loci has required complete characterization (both exons and introns) of multiple $M h c$ genes in any given species, so that PCR primers specific to the gene of interest can be designed with confidence (Edwards et al. 2000b; Hess et al. 2000; Gasper et al. 2001).

Indirect methods of surveying Mhc sequence variability, such as RFLPs and Southern blots, have proved useful in avian studies (von Schantz et al. 1996), but we believe they will ultimately be limiting in molecular ecological studies of the Mhc. Sequencing studies obviously provide more resolution, and a recent fish study suggests that only detailed knowledge of variability in relevant PBR codons will permit informed analysis of mating preferences in nature (Landry et al. 2001). Some available PCR primers for birds yield only part of PBR sequences, and these are from multiple closely related genes with unclear orthology (Edwards et al. 2000a). We have found that genomic characterization of $M h c$ loci is an essential and relatively straightforward way of increasing confidence in analysis of $M h c$ polymorphisms in birds (Edwards et al. 2000a).

Our understanding of the diversity of $M h c$ genes in various birds is growing (Hess and Edwards 2002; table 1). Compared to the mammalian $M h c$, the chicken $M h c$, or B complex, is compact, only about $100 \mathrm{~kb}$ in length, with densely packed genes containing very small $(\sim 100$ bp) introns (Kaufman et al. 1999b). In addition to the B complex, which is the locus responsible for graft rejection, chickens possess a second region containing $M h c$ genes called $R f p-Y$. Some $R f p-Y$ genes are highly polymorphic and may also be involved with disease resistance, although the latter conclusion is still debated (Afanassieff et al. 2000). The B complex of chickens has been termed "minimal essential" because of both its structural and functional minimalism; chickens express strongly only one class I and II gene, whereas other $M h c$ genes are either nonpolymorphic or expressed at low levels (Kaufman et al. 1999b). The Mhc of Japanese quail is the best-characterized avian system aside from chickens and contains more $M h c$ genes and an increased number of duplicated non-Mhc genes than does the chicken B complex (Shiina et al. 1999). Two Mhc class II genes have been discovered in the ring-necked pheasant (Wittzell et al. 1999a), and there is a second region containing $M h c$ genes that may be homologous to the chicken $R f p-Y$.

Oscine songbirds, a major clade within the perching birds (Passeriformes) comprising over 4,000 species, are useful field models for questions of mate choice and sexual selection. At the genomic level, songbird $M h c$ genes appear more numerous than in chickens (Edwards et al. 1999; Wittzell et al. 1999a), making genotyping at individual loci more challenging. The first surveys of sequence variation at individual bird $M h c$ loci in natural populations were made possible by a detailed understanding of gene intron and exon sequences (Garrigan and Edwards 1999; Hess et al. 2000; Gasper et al. 2001). These studies show that, as in chickens, only one of several blackbird Mhc genes are highly polymorphic and are under balancing selection. A diversity of class I and II genes are known to be expressed in great reed warblers (Acrocephalus arundinaceus; Westerdahl et al. 1999, 2000), and the frequency of Mhc pseudogenes appears higher in songbirds than in chickens (Hess and Edwards 2002). It has been suggested that the minimal essential model of chickens may not apply to songbirds, but further data, particularly on levels of expression of individual $M h c$ genes, are required for clarification.

\section{Mhc-Disease Associations in Birds}

If the departure by songbirds from the chicken minimal essential model holds as described above, it bodes well for studies in natural populations where combinatorial diversity at several independently segregating loci may be required for kin recognition and mating systems. However, many $M h c$ loci inevitably make genotyping more complicated, and finding strong disease associations may be facilitated by a structurally streamlined $M h c$ as in chickens (Kaufman et al. 1999b). Indeed, chickens display some of the strongest associations of Mhc and resistance/susceptibility known-much stronger than those detected thus far in mammals. The immune response to Marek's disease is particularly well characterized in chickens, and Mhc haplotype influences resistance dramatically (Schat and Xing 2000). Other pathogens for which $M h c$ genes play an important role in resistance in chickens are Rous sarcoma virus and the coccidial protist Eimeria tenella (Collins et al. 1985; Lillehoj et al. 1989). Patterns of resistance to Rous sarcoma virus support a heterozygote advantage model (Senseney et al. 2000). If mate choice in birds is influenced by disease state or susceptibility, these strong Mhc associations in chickens bode well for detecting such linkages in the wild. However, it is unclear to what extent the Mhcs of other birds will mimic the minimal essential structure and functionality of the chicken $M h c$. 


\section{Avian Mhc and Behavior}

\section{Mhc and Mate Choice in Birds}

Because birds have been the focus for a plethora of research in behavioral ecology, a deep literature already exists that is teeming with substantiated studies of behaviors in birds that are associated with $M h c$ in other animals. However, rigorous studies attempting to link $M h c$ and behavior have not yet been conducted in birds, and it is unknown whether Mhc genes may be influential via conditiondependent "good genes" models or by genetic compatibility models (Jennions and Petrie 2000). To the extent that disease resistance influences condition-dependent traits in birds, we can expect that $M h c$ genes will play a role in cues for avian mate choice that are expensive to produce in terms of energetic costs or by effects on the endocrine or the biotransformation systems (Hillgarth and Wingfield 1997; von Schantz et al. 1999). Because we expect $M h c$ type to strongly influence response to adaptive immune challenge, both during development and as an adult, a bird with $M h c$ better adapted to the pathogens in its particular environment will fare better over the course of infection. Birds in good condition should be better able to express condition-dependent traits (Hillgarth and Wingfield 1997; von Schantz et al. 1999). At their simplest, good genes models predict preference for a single $M h c$ haplotype by all females in a given environment. However, if $M h c$ heterozygosity per se is the arbiter of immunologic efficacy in avian populations (Brown 1997), mate choice will be governed primarily by compatibility and disassortative mating models, in which preference will vary among females.

The single search for an Mhc component of sexual selection in birds has been made in ring-necked pheasants Phasianus colchicus (von Schantz et al. 1996, 1997), in which an association was demonstrated between $M h c$ genotype of males and both variability in survival and expression of tarsal spur length, a condition-dependent secondary sexual characteristic predicting fitness. This work provided support for the good genes hypothesis in which females are presumed to be choosing one or a few Mhc haplotypes among males based on condition-dependent traits (Hamilton and Zuk 1982; von Schantz et al. 1989). A recent example from a natural population of deer also fits the good genes role for Mhc. Ditchkoff et al. (2001) showed that $M h c$ haplotype frequencies vary significantly among individual white-tailed deer that differed in level of parasitism and life-history traits. Using SSCP methods, Reusch et al. (2001) showed that female three-spined sticklebacks (Gasterosteus aculeatus) do not necessarily prefer genotypically dissimilar males but "count" alleles in prospective males and choose males with large numbers of alleles across four class II loci that were investigated. These examples suggest that research on Mhc correlates of condition dependence in birds and other nonmodel vertebrates will be fruitful but might take a variety of forms.

\section{Mhc Genes and Mating Systems}

Is an Mhc component to mate choice more probable under certain mating systems? Jordan and Bruford (1998) suggested that we might expect to find the effects of Mhc on mating preferences in situations in which there is a high probability of inbreeding and where a genetically based kin-recognition system would be required due to lack of social context for kin recognition. To this we add the suggestion that the effects of $M h c$ genes on mate choice are likely to be modulated by the relative importance of direct versus indirect benefits in mate-choice decisions. We can imagine a species in which direct benefits associated with mate choice are insignificant, for example, species where males contribute only genes to offspring. Lek mating systems would be good candidates for having an Mhc component to mate choice because males usually provide no care, there are no obvious direct benefits to mate choice, and offspring typically are uncertain of paternity. Additionally, in many lek systems, females copulate with but a single male, making the genetic costs of mistakes in mate choice large. Because only a few males typically enjoy mating success in such systems, Mhc as good genes models would be more appropriate than compatibility models. Secondary sexual traits play an important role in lekking systems, and this would be consistent with an Mhc component to mate choice correlating with exaggerated traits.

Long-lived species engaged in lifetime monogamy, such as many procellariiform seabirds or raptors, might be expected to show evidence of a genetically based mate-choice system, particularly ones based on genetic compatibility. Although both parents may provide care for offspring, making direct benefits critical, the genetic benefits of mate choice are also crucial when choosing a single lifelong mate. With their strong olfactory capabilities, a role for $M h c$ in mediating mate choice and inbreeding avoidance by smell is not out of the question for procellariiform birds. Genetic compatibility is not in conflict with observations of age-assortative mate choice in some seabirds because birds have the potential to choose from many individuals within an age class (Jouventin et al. 1999a), but good genes models could also explain these data. Use of information already available for many bird populations, including degree of inbreeding within a population, importance of direct and indirect benefits in mate choice, and ability to recognize kin, will allow behaviorists to choose suitable candidate species for detecting $M h c$ influences on behavior and to predict whether Mhc will influ- 
ence mate choice in ways more in line with good genes or genetic compatibility models.

\section{Immunogenetic Component to Extrapair Fertilizations?}

As several authors have noted, extrapair fertilizations (EPF), which are commonly documented in avian populations, may prove especially useful in the search for good genes effects (Hasselquist et al. 1996; Møller 1998). In studies on seminatural populations of mice (Potts et al. 1991), it was the extraterritorial mate choices by females that resulted in significant decreases of the expected number of offspring with homozygous genotypes at the $M h c$; mate preferences of females as revealed by their territorial settlement patterns suggested only weak and nonsignificant disassortative mating on the basis of $M h c$. In some birds, such as red-winged blackbirds, females may gain some direct benefits via EPFs through increased access to resources or increased protection from predators (Gray 1997). However, for many species in which territories are not adjacent to one another, or in which it is otherwise difficult for males to defend or provide care for nestlings on multiple territories, indirect benefits may be more common. There is also growing evidence for specifically immunogenetic bases for avian mate choice in EPFs. For example, in bluethroats, young from EPFs mount superior immune responses to an experimentally injected antigen than do within-pair young (Johnsen et al. 2000). The likelihood that mate choice will be modulated by $M h c$ heterozygosity, compatibility, or specific haplotypes will need to be assessed independently for each species under study.

\section{Modulation of Condition-Dependent Traits for Mate Choice by Mhc Genes}

Vocal Cues. A number of characteristics implicated in avian mate choice fulfill the criteria of condition dependence that we would expect given a role of histocompatibility genes. In some species, there is evidence that song repertoire size, song rate, or duration can influence female mating preferences (Searcy and Andersson 1986), and it has been suggested that repertoire size or other singing behaviors are honest signals of male quality. Singing could be costly in terms of energy to produce song, time spent singing, or developmental costs associated with learning (Nowicki et al. 1998). There is some evidence that males singing more song types may have higher reproductive success, provide greater parental care, and survive longer (e.g., Yasukawa et al. 1980; Lambrechts and Dhondt 1986; Hasselquist 1998; Buchanan and Catchpole 2000). It was demonstrated in great reed warblers that females obtain extrapair fertilizations from males with larger repertoires than their mates (Hasselquist et al. 1996), and repertoire size may reflect developmental condition in this same species (Nowicki et al. 2000). There is an expanding body of literature relating vocalizations with immune function and overall fitness in birds. For example, parasitic infection can decrease song rate (Møller 1991; Buchanan et al. 1999).

Visual Cues. Visual cues are commonly studied in the context of mate choice, parasite load, and survival. In many bird species, females prefer males with exaggerated plumage traits (Hill et al. 1999; Keyser and Hill 2000). These plumage traits can also predict health and survivorship; for example, in house finches (Carpodacus mexicanus), brightly plumaged males were more likely than drab males to survive Mycoplasma gallisepticum infection (Nolan et al. 1997), and parasitized birds can have dampened sexual displays and poor plumage quality (Thompson et al. 1997; Møller et al. 1999; Brawner et al. 2000). Other visual signals of condition relate to the symmetry or size of sexual characteristics. Long tail feathers or spurs have been found to signal male quality and predict survival, and females prefer these longer traits (Andersson 1982; Møller 1988, 1989; von Schantz et al. 1989, 1994). Fluctuating asymmetry of bilaterally symmetrical traits has been used as a measure of developmental stability, and there has been much interest in female preference for symmetrical males and how asymmetry can affect or predict an individual's health and fitness (Møller and Swaddle 1997). Finally, ultraviolet reflection of plumage can play a role in mate choice (Bennett et al. 1996), and individual differences in reflectance could imply a condition-dependent component.

\section{Mhc Genes and Avian Kin Recognition}

The high polymorphism of $M h c$ genes is compatible with the role for Mhc both as a modulator of condition dependence and as a kin-recognition locus. Good genes models - even those that do not incorporate a measure of heterozygosity itself as the good genes (Brown 1997; Reusch et al. 2001)—generally predict a preference for particular $M h c$ haplotypes best adapted to fighting diverse pathogens within a particular environment or temporal window. Over many seasons and exposure to numerous pathogens (both within and across seasons), good genes models, as they relate to parasite resistance, select for many different haplotypes over time. Such directional selection that varies in space and time has been documented in $M h c$ interactions with human pathogens (Hill 1991) and has the same consequences as does selection for heterozygosity, namely, high $M h c$ polymorphism. However, scenarios for $M h c$ in kin recognition or inbreeding avoidance usually do not involve global preference for a particular Mhc type by all choosers but rather involve preferences compatible with and contingent on the genes of the individual ex- 
ercising choice. Such disassortative mating also will result in high polymorphism (Potts and Wakeland 1993). In short, both good genes and kin-recognition models are consistent with balancing selection and maintenance of genetic diversity in the long term, over geographic space or in a fluctuating environment.

Vocal and Visual Cues in Kin Recognition. There is no reason to expect that many of the traits traditionally identified as useful to birds in individual recognition, such as vocalizations or visual cues (Beecher 1988; Riters and Balthazart 1998), would be under the influence of $M h c$ or immunocompetence. Many studies of individual recognition in birds focus on parent-offspring recognition, and the results vary by species and degree of selection pressure for kin recognition (Beecher 1988). For example, in colonial species where young intermingle, the pressure on parents to recognize their young is strong, whereas in noncolonial breeders, the pressure may not be so high (Beecher 1991). Accordingly, in playback experiments, colonial bank swallows were able to recognize vocalizations of their own versus unrelated young, while noncolonial rough-winged and barn swallows could not (Beecher 1991). Mates also use vocalizations to recognize one another. For example, penguins use vocalizations to locate their mates in large breeding colonies after returning from feedings at sea (Jouventin et al. 1999b; Lengagne et al. 2000). However, such individual variation is unlikely to be ultimately attributable to $M h c$ differences, unless these differences are somehow condition dependent (fig. 1). Similarly, we have no reason to expect that visual cues used in recognition of conspecifics (Watanabe et al. 1993; Shimizu 1998; Ikebuchi and Okanoya 1999) should show links with Mhc. More conserved gene systems that show consistent differences between species, rather than the interspecifically shared polymorphisms frequently found at Mhc genes, would be more logical candidates for this purpose.

Olfactory Cues. While olfaction is a key mechanism for $M h c$-mediated kin recognition and mate choice in mammals (Singer et al. 1997; Schaefer et al. 2001; reviewed in Penn 2002) and fish (Olsen et al. 1998; Reusch et al. 2001), this area of research has been almost entirely ignored in avian studies because birds generally are thought of as anosmic or microsmatic (having an unimportant or little used olfactory system). This view, however, is not justified, especially as new lines of research suggest strong olfactory roles in passerines and other avian orders (for review, Roper 1999). Petrels use olfaction to locate food (Nevitt 2000) and burrows at night (Bonadonna et al. 2001), and homing pigeons and starlings use odor cues in navigation and homing (Wallraff et al. 1995; Wallraff 2001). Furthermore, olfactory receptor genes have been characterized for chickens (Leibovici et al. 1996). The general dismissal of a functioning avian olfactory system is unfounded, especially with a rise in research illuminating the olfactory capabilities of more species of birds. The increasing number of studies conclusively demonstrating that many bird species can smell (Clark et al. 1993; Petit et al. 2002) is helping to erode the old view. However, integration between the existing avian olfaction and behavioral and ecological studies is still lacking.

A number of examples of individual recognition in birds are potentially consistent with a role for olfaction and present more plausible candidates for a role of $M h c$ in the process. Such examples include situations in which prior experience with particular individuals provide templates for future matching. Although such examples could easily be due to visual cues, some might involve olfactory cues. For example, common tern chicks Sterna hirundo visually recognize nest mates (Palestis and Burger 1999), but, like many studies, the experimental design did not rule out a role for olfaction. Perhaps the most appropriate place to search for an Mhc basis for kin recognition in birds are situations in which relatives preferentially associate with one another more so than with unrelated individuals. For example, a recent study of long-eared owls showed that individuals roosting together share higher DNA-fingerprinting band similarity than do individuals among roosts (Galeotti et al. 1997). Peacocks are able to recognize relatives without being reared with them (Petrie et al. 1999). While the mechanism for phenotype matching in these species is unknown, kin recognition clearly can be a powerful force in avian social interactions, and a role for olfaction in this process should be investigated. Such investigations will undoubtedly involve a marriage of controlled behavioral studies and applications of technology sensitive enough to detect and quantify individual differences in odor and odor preference. Should we expect that exceptional olfactory capabilities are required for an Mhc component to avian behavior? Not necessarily, particularly as demonstrated by reports of $M h c$ influences on human odor preferences (Wedekind and Füri 1997; Jacob et al. 2002).

\section{Conclusions and the Future}

Mhc genes traditionally have been the domain of immunologists, geneticists, and evolutionary biologists but should be of equal interest to avian behaviorists. They can affect a wide variety of traits when they underlie the health and vigor of an individual, making them ideal for exploring questions at the interface of behavior, immunology, and genetics. Mhc genes provide an intriguing new direction for avian behavioral ecology and may provide clues to important targets of sexual selection. Understand- 
ing genetically based mating preferences can also have practical benefits, such as better management of endangered species (Grahn et al. 1998).

The available DNA sequences for these genes in birds provide a starting point for a new generation of molecular ecological studies involving $M h c$. Still, over $10 \mathrm{yr}$ since the first chicken $M h c$ genes were cloned (Bourlet et al. 1988), there are few data bearing on this intriguing prospect. We believe the slow progress in the area of Mhc molecular ecology lies in the often daunting complexity of the $M h c$ in birds (Westerdahl et al. 1999; Wittzell et al. 1999a; Edwards et al. 2000a). However, the use of new genomics tools by ornithologists has considerably increased the accessibility of Mhc genes by PCR methods in a few species, and these new sequences have proven useful in designing primers on other, often distantly related, birds (A. Aguilar and R. Buschart, personal communication). An Mhc component should be added to studies employing other promising measures of immune response, such as ELISA detection of humoral immunity (Hasselquist et al. 1999; Raberg et al. 2000). The future of ecological immunology will no doubt bring increased attention to other avian immunomodulatory genes, such as natural killer cell receptors and cytokines. However, of all these loci, Mhc genes seem the most promising for integrating genotype, phenotype, and fitness in natural populations.

\section{Acknowledgments}

We thank C. Boake and A. Moore for organizing a fantastic symposium and for inviting us to participate in it. We thank C. Hess, A. Sih, and especially M. Silva for helpful discussion. C. Bergstrom and T. Shiina graciously allowed access to unpublished information. M. Beecher, T. Billo, G. Chambers, D. Hasselquist, A. Langefors, J. Lifjeld, S. O'Donnell, W. Potts, and A. Smith provided valuable comments on the manuscript. B.Z. was supported by a $\mathrm{Na}-$ tional Science Foundation (NSF) graduate fellowship. Our $M h c$ research was supported by NSF grants DEB- 9815800 and 0077804 .

\section{Literature Cited}

Abplanalp, H., K. Sato, D. Napolitano, and J. Reid. 1992. Reproductive performance of inbred congenic leghorns carrying different haplotypes for the major histocompatibility complex. Poultry Science 71:9-17.

Afanassieff, M., R. M. Goto, J. Ha, R. Zoorob, C. Auffrey, F. Coudert, W. E. Briles, and M. M. Miller. 2000. Are chicken Rfp-Y class I genes classical or non-classical? Pages 236-247 in M. Kasahara, ed. Major histocompatibility complex: evolution, structure and function. Springer, Tokyo.

Alberts, S. C., and C. Ober. 1993. Genetic variability in the major histocompatibility complex: a review of nonpathogen-mediated selective mechanisms. Yearbook of Physical Anthropology 36:71-89.

Andersson, M. 1982. Female choice selects for extreme tail length in a widowbird. Nature 299:818-820.

Apanius, V., D. Penn, P. R. Slev, R. Ruff, and W. K. Potts. 1997. The nature of selection on the major histocompatibility complex. Critical Reviews in Immunology 17: 179-224.

Arstila, T. P., and O. Lassila. 1993. Androgen-induced expression of the peripheral blood gamma delta $\mathrm{T}$ cell population in the chicken. Journal of Immunology 151: 6627-6633.

Beecher, M. D. 1988. Kin recognition in birds. Behavior Genetics 18:465-482.

- 1991. Successes and failures of parent-offspring recognition. Pages 94-124 in P. G. Hepper, ed. Kin recognition. Cambridge University Press, Cambridge.

Bennett, A. T. D., I. C. Cuthill, J. C. Partridge, and E. J. Maier. 1996. Ultraviolet vision and mate choice in zebra finches. Nature 380:433-435.

Bonadonna, F., J. Spaggiari, and H. Weimerskirch. 2001. Could osmotaxis explain the ability of blue petrels to return to their burrows at night? Journal of Experimental Biology 204:1485-1489.

Bourlet, Y., G. Behar, F. Guillemot, N. Frechin, A. Billault, A.-M. Chausse, R. Zoorob, and C. Auffrey. 1988. Isolation of major histocompatibility complex class II (BL) b chain sequences: comparison with mammalian a chains and expression in lymphoid organs. EMBO (European Molecular Biology Organization) Journal 7: 1031.

Brawner, W. R. I., G. E. Hill, and C. A. Sundermann. 2000. Effects of coccidial and mycoplasmal infections on carotenoid-based plumage pigmentation in male house finches. Auk 117:952-963.

Briles, W. E., R. W. Briles, and R. E. Taffs. 1983. Resistance to malignant lymphoma in chickens is mapped to subregion of major histocompatibility $(B)$ complex. Science (Washington, D.C.) 219:977-979.

Brown, J. L. 1997. A theory of mate choice based on heterozygosity. Behavioral Ecology 8:60-65.

Brown, J. L., and A. Eklund. 1994. Kin recognition and the major histocompatibility complex: an integrative review. American Naturalist 143:435-461.

Buchanan, K. L., and C. K. Catchpole. 2000. Song as an indicator of male parental effort in the sedge warbler. Proceedings of the Royal Society of London B, Biological Sciences 267:321-326.

Buchanan, K. L., C. K. Catchpole, J. W. Lewis, and A. Lodge. 1999. Song as an indicator of parasitism in the sedge warbler. Animal Behaviour 57:307-314.

Carrington, M., G. W. Nelson, M. P. Martin, T. Kissner, 
D. Vlahov, J. J. Goedert, R. Kaslow, S. Buchbinder, K. Hoots, and S. J. O’Brien. 1999. HLA and HIV-1: heterozygote advantage and $B^{*} 35-C w 04$ disadvantage. Science (Washington, D.C.) 283:1748-1752.

Clark, L., K. V. Avilova, and N. J. Bean. 1993. Odor thresholds in passerines. Comparative Biochemistry and Physiology A, Comparative Physiology 104:305-312.

Collins, W. M., D. W. Brown, P. H. Ward, W. R. Dunlop, and W. E. Briles. 1985. MHC and non-MHC genetic influences on Rous sarcoma metastasis in chickens. Immunogenetics 22:315-321.

Ditchkoff, S. S., R. L. Lochmiller, R. E. Masters, S. R. Hoofer, and R. A. Van Den Bussche. 2001. Majorhistocompatibility-complex-associated variation in secondary sexual traits of white-tailed deer (Odocoileus virginianus): evidence for good-genes advertisement. Evolution 55:616-625.

Drake, B. M., R. M. Goto, M. M. Miller, G. F. Gee, and W. E. Briles. 1999. Molecular and immunogenetic analysis of major histocompatibility haplotypes in northern bobwhite enable direct identification of corresponding haplotypes in an endangered subspecies, the masked bobwhite. Zoo Biology 18:279-294.

Edwards, S. V., E. K. Wakeland, and W. K. Potts. 1995. Contrasting histories of avian and mammalian Mhc genes revealed by class II B sequences from songbirds. Proceedings of the National Academy of Sciences of the USA 92:12200-12204.

Edwards, S. V., C. M. Hess, J. Gasper, and D. Garrigan. 1999. Toward an evolutionary genomics of the avian Mhc. Immunological Reviews 167:119-132.

Edwards, S. V., J. Nusser, and J. Gasper. 2000a. Characterization and evolution of Mhc genes from non-model organisms, with examples from birds. Pages 168-207 in A. J. Baker, ed. Molecular methods in ecology. Blackwell Scientific, Cambridge.

Edwards, S. V., J. Gasper, D. Garrigan, D. A. Martindale, and B. F. Koop. 2000b. A 39-kb sequence around a blackbird Mhc class II B gene: ghost of selection past and songbird genome architecture. Molecular Biology and Evolution 17:1384-1395.

Galeotti, P., A. Pilastro, G. Tavecchia, A. Bonetti, and L. Congiu. 1997. Genetic similarity in long-eared owl communal winter roosts: a DNA fingerprinting study. Molecular Ecology 6:429-435.

Garrigan, D., and S. V. Edwards. 1999. Polymorphism across an exon-intron boundary in an avian $M h c$ class II $B$ gene. Molecular Biology and Evolution 16: 1599-1606.

Gasper, J., T. Shiina, H. Inoko, and S. V. Edwards. 2001. Songbird genomics: analysis of $45-\mathrm{kb}$ upstream of a polymorphic Mhc class II gene in red-winged blackbird (Agelaius phoeniceus). Genomics 75:26-34.
Gerencer, M., M. Tajic, V. Kerhin-Brkljacic, and A. Kastelan. 1982. An association between serum testosterone level and HLA phenotype. Immunology Letters 4: 155-158.

Grafen, A. 1990. Do animals really recognize kin? Animal Behaviour 39:42-54.

Grahn, M., A. Langefors, and T. von Schantz. 1998. The importance of mate choice in improving viability in captive populations. Pages 341-363 in T. Caro, ed. Behavioral ecology and conservation biology. Oxford University Press, New York.

Gray, E. M. 1997. Female red-winged blackbirds accrue material benefits from copulating with extra-pair males. Animal Behaviour 53:625-639.

Hamilton, W. D., and M. Zuk. 1982. Heritable true fitness and bright birds: a role for parasites? Science (Washington, D.C.) 218:384-387.

Hasselquist, D. 1998. Polygyny in great reed warblers: a long-term study of factors contributing to male fitness. Ecology 79:2376-2390.

Hasselquist, D., S. Bensch, and T. von Schantz. 1996. Correlation between male song repertoire, extra-pair paternity and offspring survival in the great reed warbler. Nature 381:229-232.

Hasselquist, D., J. A. Marsh, P. W. Sherman, and J. C. Wingfield. 1999. Is avian humoral immunocompetence suppressed by testosterone? Behavioral Ecology and Sociobiology 45:167-175.

Hess, C. M., and S. V. Edwards. 2002. The evolution of major histocompatibility genes in birds. BioScience 52 : 423-431.

Hess, C. M., J. Gasper, H. Hoekstra, C. Hill, and S. V. Edwards. 2000. MHC class II pseudogene and genomic signature of a 32-kb cosmid in the house finch (Carpodacus mexicanus). Genome Research 10:613-623.

Hill, A. V. 1999. Genetics and genomics of infectious disease susceptibility. British Medical Bulletin 55:401-413.

Hill, A. V. S. 1991. HLA associations with malaria in Africa: some implications for MHC evolution. Pages 403-420 in J. Klein and D. Klein, eds. Molecular evolution of the major histocompatibility complex. Springer, Berlin.

Hill, G. E., P. M. Nolan, and A. M. Stoehr. 1999. Pairing success relative to male plumage redness and pigment symmetry in the house finch: temporal and geographic constancy. Behavioral Ecology 10:48-53.

Hillgarth, N., and J. C. Wingfield. 1997. Parasite-mediated sexual selection: endocrine aspects. Pages 78-104 in D. H. Clayton and J. Moore, eds. Host-parasite evolution: general principles and avian models. Oxford University Press, Oxford.

Ikebuchi, M., and K. Okanoya. 1999. Male zebra finches and Bengalese finches emit directed songs to the video 
images of conspecific females projected onto a TFT display. Zoological Science 16:63-70.

Jacob, S., M. K. McClintock, B. Zelano, and C. Ober. 2002. Paternally inherited HLA alleles are associated with women's choice of male odor. Nature Genetics 30: 175-179.

Janeway, C. A., P. Travers, M. Walport, and J. D. Capra. 1999. Immunobiology: the immune system in health and disease. Current Biology Publications, London.

Jarvi, S. I., R. M. Goto, G. F. Gee, W. E. Briles, and M. M. Miller. 1999. Identification, inheritance, and linkage of $B$-G-like and MHC class I genes in cranes. Journal of Heredity 90:152-159.

Jennions, M. D., and M. Petrie. 2000. Why do females mate multiply? a review of the genetic benefits. Biological Reviews of the Cambridge Philosophical Society 75: 21-64.

Johnsen, A., V. Andersen, C. Sunding, and J. T. Lifjeld. 2000. Female bluethroats enhance offspring immunocompetence through extra-pair copulations. Nature 406: 296-299.

Jordan, W. C., and M. W. Bruford. 1998. New perspectives on mate choice and the MHC. Heredity 81:239-245.

Jouventin, P., B. Lequette, and F. S. Dobson. 1999a. Agerelated mate choice in the wandering albatross. Animal Behaviour 57:1099-1106.

Jouventin, P., T. Aubin, and T. Lengagne. 1999b. Finding a parent in a king penguin colony: the acoustic system of individual recognition. Animal Behaviour 57: $1175-1183$.

Kaufman, J., and H. J. Wallny. 1996. Chicken MHC molecules, disease resistance and the evolutionary origin of birds. Current Topics in Microbiology and Immunology 212:129-141.

Kaufman, J., S. Milne, B. A. Walker, J. P. Jacob, C. Auffray, R. Zoorob, and S. Beck. 1999a. The chicken B locus is a minimal essential major histocompatibility complex. Nature 401:923-925.

Kaufman, J., J. Jansen, I. Shaw, B. Walker, S. Milne, S. Beck, and J. Salamonsen. 1999b. Gene organization determines the evolution of function in the chicken MHC. Immunological Reviews 167:101-117.

Keyser, A. J., and G. E. Hill. 2000. Structurally based plumage coloration is an honest signal of quality in male blue grosbeaks. Behavioral Ecology 11:202-209.

Knapp, L. A., J. C. Ha, and G. P. Sackett. 1996. Parental Mhc antigen sharing and pregnancy wastage in captive pig-tailed macaques. Journal of Reproductive Immunology 32:73-88.

Lambrechts, M., and A. A. Dhondt. 1986. Male quality, reproduction, and survival in the great tit (Parus major). Behavioral Ecology and Sociobiology 19:57-64.

Landry, C., D. Garant, P. Duchesne, and L. Bernatchez.
2001. "Good genes as heterozygosity": the major histocompatibility complex and mate choice in Atlantic salmon (Salmo salar). Proceedings of the Royal Society of London B, Biological Sciences 268:1279-1285.

Langefors, A., J. Lohm, M. Grahn, Ø. Andersen, and T. von Schantz. 2001. Association between major histocompatibility complex class II B alleles and resistance to Aeromonas salmonicida in Atlantic salmon. Proceedings of the Royal Society of London B, Biological Sciences 268:479-485.

Larsen, B., C. A. King, M. Simms, and V. M. Skanes. 2000. Major histocompatibility complex phenotypes influence serum testosterone concentration. Rheumatology 39: 758-763.

Leibovici, M., F. Lapointe, P. Aletta, and C. A. Lièvre. 1996. Avian olfaction receptors: differentiation of olfactory neurons under normal and experimental conditions. Developmental Biology 175:118-131.

Lengagne, T., T. Aubin, P. Jouventin, and J. Lauga. 2000. Perceptual salience of individually distinctive features in the calls of adult king penguins. Journal of the Acoustical Society of America 107:508-516.

Lillehoj, H. S., M. D. Ruff, L. D. Bacon, S. J. Lamont, and T. K. Jeffers. 1989. Genetic control of immunity to Eimeria tenella. Interaction of MHC genes and nonMHC linked genes influences levels of disease susceptibility in chickens. Veterinary Immunology and Immunopathology 20:135-148.

Magor, B. G., A. de Tomaso, B. Rinkevich, and I. L. Weissman. 1999. Allorecognition in colonial tunicates: protection against predatory cell lineages? Immunological Reviews 167:69-79.

Martin-Villa, J. M., J. Longás, and A. Arnáiz-Villena. 1999. Cyclic expression of HLA class I and II molecules on the surface of purified spermatozoa and their control by serum inhibin B levels. Biology of Reproduction 61: 1381-1386.

Meager, S., and W. K. Potts. 1997. A microsatellite-based MHC genotyping system for house mice (Mus domesticus). Hereditas (Lund) 127:75-82.

Møller, A. P. 1988. Female choice selects for male sexual tail ornaments in the monogamous swallow. Nature 332: 640-642.

-1989. Viability costs of male tail ornaments in a swallow. Nature 339:132-135.

- 1991. Parasite load reduces song output in a passerine bird. Animal Behaviour 41:723-730.

- 1998. Sperm competition and sexual selection. Pages 55-90 in T. R. Birkhead and A. P. Møller, eds. Sperm competition and sexual selection. Academic Press, New York.

Møller, A. P., and J. P. Swaddle. 1997. Asymmetry, devel- 
opmental stability and evolution. Oxford University Press, Oxford.

Møller, A. P., P. Christe, and E. Lux. 1999. Parasitism, host immune function, and sexual selection. Quarterly Review of Biology 74:3-20.

Nevitt, G. A. 2000. Olfactory foraging by Antarctic procellariiform seabirds: life at high Reynolds numbers. Biological Bulletin 198:245-253.

Nolan, P. M., G. E. Hill, and A. M. Stoehr. 1997. Sex, size, and plumage redness predict house finch survival in an epidemic. Proceedings of the Royal Society of London B, Biological Sciences 265:961-965.

Nowicki, S., S. Peters, and J. Podos. 1998. Song learning, early nutrition and sexual selection in songbirds. American Zoologist 38:179-190.

Nowicki, S., D. Hasselquist, S. Bensch, and S. Peters. 2000. Nestling growth and song repertoire size in great reed warblers: evidence for song learning as an indicator in mate choice. Proceedings of the Royal Society of London B, Biological Sciences 267:2419-2424.

Ober, C., T. Hyslop, S. Elias, L. R. Weitkamp, and W. W. Hauck. 1998. Human leukocyte antigen matching and fetal loss: results of a 10-year prospective study. Human Reproduction 13:33-38.

Olsen, K. H., M. Grahn, J. Lohm, and A. Langefors. 1998. MHC and kin discrimination in juvenile Arctic charr, Salvelinus alpinus (L.). Animal Behaviour 56:319-327.

Palestis, B. G., and J. Burger. 1999. Individual sibling recognition in experimental broods of common tern chicks. Animal Behaviour 58:375-381.

Paterson, S., K. Wilson, and J. M. Pemberton. 1998. Major histocompatibility complex variation associated with juvenile survival and parasite resistance in a large unmanaged ungulate population. Proceedings of the National Academy of Sciences of the USA 95:3714-3719.

Penn, D. J. 2002. The scent of genetic compatibility: sexual selection and the major histocompatibility complex. Ethology 108:1-21.

Penn, D. J., and W. K. Potts. 1999. The evolution of mating preferences and major histocompatibility complex genes. American Naturalist 153:145-164.

Petit, C., M. Hossaert-McKey, P. Perret, J. Blondel, and M. M. Lambrechts. 2002. Blue tits use selected plants and olfaction to maintain an aromatic environment for nestlings. Ecology Letters 5:585-589.

Petrie, M., A. Krupa, and T. Burke. 1999. Peacocks lek with relatives even in the absence of social and environmental cues. Nature 401:155-157.

Potts, W. K., and E. K. Wakeland. 1993. Evolution of MHC genetic diversity - a tale of incest, pestilence and sexual preference. Trends in Genetics 9:408-412.

Potts, W. K., C. J. Manning, and E. K. Wakeland. 1991.
Mating patterns in seminatural populations of mice influenced by MHC genotype. Nature 352:619-621.

Potts, W. P., and P. R. Slev. 1995. Pathogen-based models favoring $\mathrm{MHC}$ genetic diversity. Immunological Reviews 143:181-197.

Puel, A., and D. Mouton. 1996. Genes responsible for quantitative regulation of antibody production. Critical Reviews in Immunology 16:223-250.

Raberg, L., J. A. Nilsson, P. Ilmonen, M. Stjernman, and D. Hasselquist. 2000. The cost of an immune response: vaccination reduces parental effort. Ecology Letters 3: 382-386.

Reusch, T. B., M. A. Haberli, P. B. Aeschlimann, and M. Milinski. 2001. Female sticklebacks count alleles in a strategy of sexual selection explaining MHC polymorphism. Nature 414:300-302.

Riters, L. V., and J. Balthazart. 1998. Behavioral evidence for individual recognition in Japanese quail. Behaviour 135:551-578.

Roper, T. J. 1999. Olfaction in birds. Advances in the Study of Behavior 28:247-332.

Schaefer, M. L., D. A. Young, and D. Restrepo. 2001. Olfactory fingerprints for major histocompatibility complex-determined body odors. Journal of Neuroscience 21:2481-2487.

Schaffer, E., A. Sette, D. L. Johnson, M. C. Bekoff, J. A. Smith, H. M. Grey, and S. Buus. 1989. Relative contribution of "determinant selection" and "holes in the Tcell repertoire" to T-cell responses. Proceedings of the National Academy of Sciences of the USA 86: 4649-4653.

Schat, K. A., and Z. Xing. 2000. Specific and nonspecific immune responses to Marek's disease virus. Developmental and Comparative Immunology 24:201-221.

Searcy, W. A., and M. Andersson. 1986. Sexual selection and the evolution of song. Annual Review of Ecology and Systematics 17:507-533.

Senseney, H. L., W. E. Briles, H. Abplanalp, and R. L. Taylor, Jr. 2000. Allelic complementation between MHC haplotypes $\mathrm{B}(\mathrm{Q})$ and $\mathrm{B} 17$ increases regression of Rous sarcomas. Poultry Science 79:1736-1740.

Shiina, T., C. Shimizu, A. Oka, Y. Teraoka, T. Imanishi, T. Gojobori, K. Hanzawa, S. Watanabe, and H. Inoko. 1999. Gene organization of the quail major histocompatibility complex (MhcCoja) class I region. Immunogenetics 49:384-394.

Shimizu, T. 1998. Conspecific recognition in pigeons ( $\mathrm{Co}-$ lumbia livia) using dynamic video images. Behaviour 135:43-53.

Singer, A. G., G. K. Beauchamp, and K. Yamazaki. 1997. Volatile signals of the major histocompatibility complex in male mouse urine. Proceedings of the National Academy of Sciences of the USA 94:2210-2214. 
Slade, R. W., and H. I. McCallum. 1992. Overdominant versus frequency-dependent selection at MHC loci. Genetics 132:861-862.

Thompson, C. W., N. Hillgarth, M. Leu, and H. E. McClure. 1997. High parasite load in house finches (Carpodacus mexicanus) is correlated with reduced expression of a sexually selected trait. American Naturalist 149: 270-294.

Thursz, M. R., H. C. Thomas, B. M. Greenwood, and A. V. S. Hill. 1997. Heterozygote advantage for HLA classII type in hepatitis B virus infection. Nature Genetics $17: 11-12$.

Tregenza, T., and N. Wedell. 2000. Genetic compatibility, mate choice and patterns of parentage: invited review. Molecular Ecology 9:1013-1027.

Van Valen, L. 1973. A new evolutionary law. Evolutionary Theory 1:1-30.

Vincek, V., D. Klein, R. T. Graser, C. Figueroa, O’Huigin, and J. Klein. 1995. Molecular cloning of major histocompatibility complex class II B gene cDNA from the Bengalese finch, Lonchura striata. Immunogenetics 42: 262-267.

Vincek, V., C. O’Huigin, Y. Satta, N. Takahata, P. T. Boag, P. R. Grant, B. R. Grant, and J. Klein. 1997. How large was the founding population of Darwin's finches? Proceedings of the Royal Society of London B, Biological Sciences 264:111-118.

von Schantz, T., G. Goransson, G. Andersson, I. Froberg, M. Grahn, A. Helgee, and H. Wittzell. 1989. Female choice selects for a viability-based male trait in pheasants. Nature 337:166-169.

von Schantz, T., M. Grahn, and G. Goransson. 1994. Intersexual selection and reproductive success in the pheasant Phasianus colchicus. American Naturalist 144: 510-527.

von Schantz, T., H. Wittzell, G. Goransson, M. Grahn, and K. Persson. 1996. MHC genotype and male ornamentation: genetic evidence for the Hamilton-Zuk model. Proceedings of the Royal Society of London B, Biological Sciences 263:265-271.

von Schantz, T., H. Wittzell, G. Goransson, and M. Grahn. 1997. Mate choice, male condition-dependent ornamentation and MHC in the pheasant. Hereditas (Lund) 127:133-140.

von Schantz, T., S. Bensch, M. Grahn, D. Hasselquist, and
H. Wittzell. 1999. Good genes, oxidative stress and condition-dependent sexual signals. Proceedings of the Royal Society of London B, Biological Sciences 266: $1-12$.

Wallraff, H. G. 2001. Navigation by homing pigeons: updated perspective. Ethology Ecology and Evolution 13: $1-48$.

Wallraff, H. G., J. Kiepenheuer, M. F. Neumann, and A. Streng. 1995. Homing experiments with starlings deprived of the sense of smell. Condor 97:20-26.

Watanabe, S., M. Yamashita, and M. Wakita. 1993. Discrimination of video images of conspecific individuals in Bengalese finches. Journal of Ethology 11:67-72.

Wedekind, C. 1994. Mate choice and maternal selection for specific parasite resistances before, during and after fertilization. Philosophical Transactions of the Royal Society of London B, Biological Sciences 346:303-311.

Wedekind, C., and S. Füri. 1997. Body odour preferences in men and women: do they aim for specific MHC combinations or simply heterozygosity? Proceedings of the Royal Society of London B, Biological Sciences 264: 1471-1479.

Westerdahl, H., H. Wittzell, and T. von Schantz. 1999. Polymorphism and transcription of Mhc class I genes in a passerine bird, the great reed warbler. Immunogenetics 49:158-170.

- 2000. Mhe diversity in two passerine birds: no evidence for a minimal essential Mhc. Immunogenetics 52:92-100.

Wittzell, H., A. Bernot, C. Auffray, and R. Zoorob. 1999a. Concerted evolution of two Mhc class II B loci in pheasants and domestic chickens. Molecular Biology and Evolution 16:479-490.

Wittzell, H., T. Madsen, H. Westerdahl, R. Shine and T. von Schantz. 1999b. MHC variation in birds and reptiles. Genetica 104:301-309.

Yamazaki, K., E. A. Boyse, V. Mike, H. T. Thaler, B. J. Mathieson, J. Abbott, J. Boyse, Z. A. Zayas, and L. Thomas. 1976. Control of mating preferences in mice by genes in the major histocompatibility complex. Journal of Experimental Medicine 144:1324-1335.

Yasukawa, K., J. L. Blank, and C. B. Patterson. 1980. Song repertoires and sexual selection in the red-winged blackbird. Behavioral Ecology and Sociobiology 7:233-238. 